\title{
Istanbul 2006
}

\author{
By Gönül Dönmez-Colin
}

Fall 2006 Issue of KINEMA

\section{ISTANBUL INTERNATIONAL FILM FESTIVAL 2006}

A quarter of a century old, Istanbul International Film Festival (April 1-16, 2006) has come a long way. The galas, the distinguished guests - no less than Catherine Deneuve and Gérard Depardieu - special screenings, celebrations, homages, tributes, documentaries, films from the world film festivals, Turkish cinema, human rights and freedom to women sections, and last but not the least, the competition. In Istanbul, you can find more sections than the total number of films shown in some festivals. Then again, this is a festival that wears several hats: a film festival that tries to bring the best of the latest to its discerning audience; a showcase that aims at displaying the most recent crop of Turkish cinema to the foreign guests; and a two-week long cinematheque for the film lovers, trying to fill the gap left when the city's cinematheque was closed many years ago by one of the cuntas and never re-opened.

The opening film of this year was Merry Christmas by Christian Carion, a France-Germany-UK- BelgiumRomania co-production inspired by an actual event from WWI, which sounds more fiction than fact. In the hands of Carion, who used his filmic licence rather liberally, it rolled more like a fairy tale. After all, what would you call it when men broken by war are trembling in the ditches in their overcoats, a beautiful blond woman sings her heart out in a sheer little garment, oblivious to the sub-zero temperature! Cynicism aside, this is a war film that touches the hearts of many and when violence is raging everywhere around us, it gives hope to the hopeful to see enemies shaking hands because it is Christmas.

In the international competition section, films on themes of arts and artists or adaptations from literary works competed for the Golden Tulip. A delightful work in this section was Kan shang qu hen mei (Little Red Flowers) by talented sixth generation director, Zhang Yuan. Based on a novel by Wang Shuo, entitled Could be Beautiful, this wonderful film told the story of a precocious little boy left alone in a boarding school where individuality has to be restrained for "one's own good." The time is ripe for such "education" as the Communist Revolution has just settled in, but little Qiang is too bright to be a plain conformist.

The competition for Turkish cinema displayed a wide range of films that could not give a reasonable idea to the foreign guests as to the direction Turkish cinema has taken. There were as many styles and stands as there were films, and local opinion differed rather sharply from the foreign one. Hacivat karagöz neden öldürüldü? (Killing the Shadow) by Ezel Akay was the favourite of the local critics but most foreigners missed the point amidst all the seemingly unnecessary screaming. Dondurmam kaymak (Ice Cream, I Scream) did not leave much impression either although we've learned later that it was chosen as Turkey's entry to the Oscars.

Mustafa Altoklar is an important filmmaker in his own right although most of the time, he catches the attention of the local press by simply being "mediatic" as they call him. His Beyza'nin kadnlar (Shattered Soul) was shot meticulously and had it possessed a more balanced and plausible script, it could have been a successful experiment of a little explored genre in contemporary Turkish cinema-crime thriller. Furthermore, the identity question, which seems to be at the core of the narrative, could have given the film a definite socio-political dimension had it been exploited more deeply and this would have brought the film to another level, more in tune with the present Turkish reality. Instead, the protagonists' different personalities - good housewife, sex maniac, selfless schoolteacher, religious fundamentalist, etc etc- were left up in the air and did not lead to a coherent thought process.

Iki genç kz (Two Girls) by prolific Kutlug Ataman has made the rounds of many festivals before being shown in this festival. It is a vibrant, poignant coming of age story involving two girls - one from a traditional family from the outskirts of town and the other from a fractured family uptown. But this is not a poor kid, rich kid story, as neither is rich. However, the values of their environments are different. The excellent music by Turkish pop group Replicas, the performances of the two girls and particularly Hülya Avar's performance as the childlike mother of the uptown girl are remarkable. The film catches some foreigners off-guard who think Turkey is a rural country where all women cover themselves and adhere to the dictates of Islam. They 
wonder if the lifestyles depicted in the film reflect the reality. After all, how can Muslim girls be so free, or even "promiscuous" as one critic commented. For those weaned on socially committed rural dramas when it comes to so-called "developing world" cinema, Two Girls is an eye-opener, and there is nothing exaggerated about it.

One film in this section left a strong impression on the foreign audience. Be vakit Times and Winds) by Reha Erdem. This is one director who is not afraid to try different genres and different subject matters but it is not very hard to find a running thread through his films, or a prominent theme such as humanity and the pains of being a human being in a rapidly changing world. Daily life in a little village is structured around the five prayer times and three children are captured by the flow of time. There is pain but each pain gives the strength to cling to life evermore. A moving film that handles its subject in a subtle way.

In the same section, Babam ve Olum (My Father and Son) by Çaan Irmak was one of those three-handkerchief films although local audience gave it full support. At the core of the film is the military coup of 1980 and its pains but an earnest confrontation with this painful history has not happened yet in Turkish cinema. Now and then filmmakers pick up the subject but turn around it in such an abstract way that those who are not familiar with this dark spot in Turkish history are perplexed to say the least.

As the films in various international sections of the festival have already been shown elsewhere and have been written about extensively, perhaps it is more reasonable to continue the voyage with the Turkish films and take a look at the section, "Award Winning Turkish Films of 25 Years." A gem from Atf Ylmaz, the master of masters who passed away in May leaving behind countless films, Bir yudum sevgi (A Taste of Love, 1984) celebrates women with choices. It is the eighties and feminism has finally arrived in Turkey and one cannot expect less from Atf Bey, affectionately called "the director of women"s films'. In another Atf Ylmaz gem, Ad Vasfiye (Her Name is Vasfiye, 1986), four men who have played an important role in her life describe one woman-woman as seen from man's point of view. Amansz Yol (Desperate Road, 1985), Anayurt Oteli (Motherland Hotel, 1986), Gizli yüz (Secret Face) and Akrebin yolculuu (Journey of the Clockhand, 1997) from the only true "auteur" of Turkish cinema, Ömer Kavur, who also passed away not long ago; Mays sknts (Clouds of May, 1999) and Uzak (Distant, 2002), by Nuri Bilge Ceylan, the Turkish Tarkovsky according to many critics. These are only a handful of Turkish films that have made their mark over the last twenty-five years.

Last but not the least was an important tribute to an important figure, Erden Kral, with screenings of not only Hakkâride Bir Mevsim (A Season in Hakkâri, 1983) and Mav Sürgün (The Blue Exile, 1993), but also a rare piece, Ayna (The Mirror, 1984), which holds the mirror to the inner world of a young peasant woman torn between duty and desire.

\section{References}

\section{AWARDS}

Golden Tulip

A Cock and Bull Story by Michael Winterbottom

FIPRESCI Award

International Competition

A Cock and Bull Story by Michael Winterbottom

National Competition

Times and Winds by Reha Erdem

National Competition Best Turkish film

Times and Winds by Reha Erdem

Best Director Kutlug Ataman for Two Girls 


\section{Author Information}

Gönül DÖNMEZ-COLIN is an independent researcher and writer whose publications include Women, Islam and Cinema, Cinemas of the Other: A personal Journey with Filmmakers from the Middle East and Central Asia, Cinema of North Africa and the Middle East (ed.); Turkish Cinema: Identity, Distance and Belonging (Reaktion Books), and Routledge Dictionary of Turkish Cinema (2014). 